УДК 376.112.4

DOI https://doi.org/10.26661/2522-4360-2021-2-19

\title{
ОСОБЛИВОСТІ ОРГАНІЗАЦІЇ ІНКЛЮЗИВНОГО НАВЧАННЯ У ПОЧАТКОВІЙ ШКОЛІ
}

\author{
Гордіснко Т. В. \\ кандидат педагогічних наук, \\ доиент кафедри педагогіки, початкової освіти та освітнього менеджменту, \\ Ніжинський державний університет імені Миколи Гоголя \\ вул. Графська, 2, Ніжин, Чернігівська область, Україна \\ orcid.org/0000-0002-4662-1895 \\ hordienkotana@gmail.com, \\ Дубровська Л. О. \\ кандидат педагогічних наук, доцент кафедри педагогіки, \\ початкової освіти та освітнього менеджменту \\ Ніжинський державний університет імені Миколи Гоголя \\ вул. Графська, 2, Ніжин, Чернігівська область, Україна \\ orcid.org/0000-0001-7158-6115 \\ dudrovskie9@gmail.com \\ Дубровський В. Л. \\ старший викладач кафедри педагогіки, початкової освіти \\ та освітнього менеджменту \\ Ніжинський державний університет імені Миколи Гоголя \\ вул. Графська, 2, Ніжин, Чернігівська область, Україна \\ orcid.org/0000-0002-0902-1962 \\ dubrovsky@ex.ua
}

\begin{abstract}
Ключові слова: інклюзія, інклюзивна освіта, особливі освітні потреби, особи з особливими освітніми потребами, універсальне безбар'єрне середовище.
\end{abstract}

У статті інклюзивна освіта розглядається як спосіб навчання, який має великі перспективи в сучасному суспільстві. Метою статті є здійснення аналізу особливостей інклюзивного навчання в сучасній початковій школі. Спеціалізація моделі розвитку ідеї інклюзивної освіти визначається кількома рівнями соціально-психологічних змін, кожен з яких потребує визначення механізмів впровадження, динамічних показників, критеріїв оцінки та основних суб'єктів змін, такими як: системний рівень, організаційний рівень, груповий рівень, індивідуальний рівень. Проаналізовано принципи інклюзивної освіти здобувачів початкової освіти з особливими освітніми потребами в закладах загальної середньої освіти, котрі базуються на таких підходах, методах, формах, як: індивідуальний навчальний план та індивідуальна освітня програма дитини $з$ розвитку академічних знань і життєвих компетенцій; соціальна реабілітація дитини в освітній установі і поза нею; психолого-педагогічний супровід; психологопедагогічний консиліум; індивідуальна психолого-педагогічна карта розвитку здобувача початкової освіти; портфоліо здобувача початкової освіти 3 особливими освітніми потребами; компетентність вчителя; тьюторський супровід; адаптивне освітнє середовище; згуртування колективу; формування та розвиток толерантного сприйняття.

Розглянуто умови створення універсального безбар'єрного середовища для здобувачів початкової освіти 3 особливими освітніми потребами: 
матеріально-технічна база закладу освіти; інформаційно-організаційне забезпечення освітнього процесу; організаційно-педагогічне забезпечення, що включає реалізацію освітніх програм із урахуванням особливостей психофізичного розвитку та можливостей дітей із особливими освітніми потребами; програмно-методичне забезпечення освітнього процесу; комплексний психолого-педагогічний супровід; кадрове забезпечення.

\title{
PECULIARITIES OF THE ORGANIZATION OF INCLUSIVE EDUCATION IN PRIMARY SCHOOL
}

\author{
Hordienko T. V. \\ Candidate of Pedagogical Sciences, \\ Associate Professor at the Department of Pedagogy, \\ Primary Education and Educational Management \\ Mykola Gogol Nizhyn State University \\ Grafska str., 2, Nizhyn, Chernihiv region, Ukraine \\ orcid.org/0000-0002-4662-1895 \\ hordienkotana@gmail.com \\ Dubrovska L. $O$. \\ Candidate of Pedagogical Sciences, \\ Associate Professor at the Department of Pedagogy, \\ Primary Education and Educational Management \\ Mykola Gogol Nizhyn State University \\ Grafska str., 2, Nizhyn, Chernihiv region, Ukraine \\ orcid.org/0000-0001-7158-6115 \\ dudrovskie9@gmail.com
}

Dubrovsky V. L. Senior Lecturer at the Department of Pedagogy, Primary Education and Educational Management Mykola Gogol Nizhyn State University Grafska str., 2, Nizhyn, Chernihiv region, Ukraine orcid.org/0000-0002-0902-1962 dubrovsky@ex.ua

Key words: inclusion, inclusive education, special educational needs, people with special educational needs, universal barrier-free environment.
The article considers inclusive education as a way of learning that has great prospects in modern society. Every child with disabilities will be able to exercise the right to receive a quality education adapted to their abilities and needs, to find their place in life and to realize their life potential. The purpose of the article is to analyze the features of inclusive education in modern primary school.

The specialization of the model of development of the idea of inclusive education is determined by several levels of socio-psychological changes, each of which requires the definition of implementation mechanisms, dynamic indicators, evaluation criteria and main subjects of change: system level, organizational level, group level, individual level.

The principles of inclusive education of primary school students with special educational needs in general secondary education institutions are analyzed, which are based on the following approaches, methods, forms: individual curriculum and individual educational program of a child for the development of academic knowledge and life competencies; social rehabilitation of the child in the educational institution and outside it; psychological and pedagogical support; psychological and pedagogical council; individual psychological and pedagogical map of the development of the applicant for primary education; 
portfolio of primary education seekers with special educational needs; teacher competence; tutoring; adaptive educational environment; team cohesion; formation and development of tolerant perception.

The conditions for creating a universal barrier-free environment for primary education students with special educational needs are considered: material and technical base of the educational institution; information and organizational support of the educational process; organizational and pedagogical support, which includes the implementation of educational programs taking into account the peculiarities of psychophysical development and the capabilities of children with special educational needs; software and methodological support of the educational process; comprehensive psychological and pedagogical support; staffing.

Постановка проблеми. Інклюзію в освіті відображають принципи, які полягають в доступності шкільної освіти для всіх дітей: забезпечення фізичного доступу учнів з обмеженими можливостями здоров'я в школи; розробення мобільної структури навчальної програми та різноманітних освітніх методик, які дозволяють задовольнити потреби всіх учнів, у тому числі: потреби в повноцінному і різноманітному особистісному становленні та розвитку з урахуванням індивідуальних схильностей, інтересів, мотивів і здібностей (особистісна успішність); потреби в органічному входженні особистості в соціальне оточення і плідній участі в житті суспільства (соціальна успішність); потреби в розвиненості у особистості універсальних трудових і практичних умінь, готовності до вибору професії (професійна успішність).

Інклюзія на сучасному етапі розвитку освіти $€$ одним із варіантів включення дитини 3 особливими освітніми потребами в загальноосвітній простір, а це означає, що створено адаптоване освітнє середовище, надаються додаткові освітні послуги і відчутна користь від спільного навчання дітей 3 особливими освітніми потребами зі здоровими однокласниками.

Вровадження інклюзії нерозривно пов'язане 3 демократизацією усіх сфер життя та визнанням за кожною людиною права на повноцінне життя й освіту та створення спеціального освітнього середовища, яке б дозволило забезпечити адекватні можливості й умови для отримання освіти в межах освітніх стандартів. Таким особливостям організації інклюзивного навчання саме в початковій школі і буде присвятена наша стаття.

Аналіз досліджень і публікацій. У процесі реформ і трансформування освітньої системи України організація інклюзивного навчання є особливою умовою, на якій останнім часом доволі часто фокусується дослідницька увага дослідників і науковців.

У вітчизняній і зарубіжній педагогічній науці склалося чітке усвідомлення проблеми доступного освітнього середовища (I. Бех, С. Бондаревська, Дж. Гібсон, К. Князева, С. Капиця, І. Пригожин, І. Стенгерс, В. Ясвін та ін.).

На сучасному етапі розвитку наукової думки відбувається активне обговорення питань ефек- тивного включення в освітній процес дітей з особливими освітніми потребами та розроблення підходів до організації інклюзивного навчання в умовах закладів загальної середньої освіти. Аспектам інтегрованого навчання дітей 3 особливими освітніми потребами приділяли увагу науковці в галузі корекційної, соціальної та спеціальної педагогіки, серед них: Л. Аксьонова, В. Бондар, С. Бондаренко, М. Веденіна, М. Власова, О. Глоба, В. Григоренко, П. Горностай, Г. Іващенко, Б. Пузанов, О. Установ.

Останнє десятиліття багате науковими пошуками i дослідженнями проблем інклюзивної освіти українських науковців Ю. Богінської, В. Болдирєвої, В. Бондар, А. Колупаєвої, Т. Свтухової, В. Ляшенко, І. Іванової, В. Синьова, О. Столяренко, А. Шевчук, О. Савченко. У працях науковців розкриваються питання інтегрованого навчання здобувачів освіти.

Мета статті - здійснити аналіз особливостей інклюзивного навчання в сучасній початковій школі.

Виклад основного матеріалу. Спеціалізація моделі розвитку ідеї інклюзивної освіти визначається кількома рівнями соціально-психологічних змін, кожен 3 яких потребує визначення механізмів впровадження, динамічних показників, критеріїв оцінки та основних суб'єктів змін.

1. Системний рівень змін визначається державною та регіональною політикою, вимагає моніторингових програм і забезпечує основні інституційні умови для системного розвитку інклюзивного процесу.

2. Організаційний рівень забезпечується діяльністю освітньої організації, вибудовуючись як культура, традиції та основні принципи, за якими проектується освітній процес конкретної школи. Створення спеціальних освітні умов, класифікація кадрів, готовність школи до відкритого діалогу із соціальним оточенням і батьками, система підтримки і професійна взаємодія визначають динаміку змін на цьому рівні.

3. Груповий рівень - важливий соціально-психологічний рівень процесу включення, на якому вирішується головне питання: чи буде прийнятий «особливий» учень в колектив однолітків, чи може він стати активним учасником шкільної спільноти. 
Основним об'єктом змін стає сфера освітніх відносин і навчальної взаємодії в класі. Для соціально-психологічних та фізичних вимірів на цьому рівні інклюзивного процесу застосовуються соціометричні інструменти та соціо-психологічні засоби.

4. Індивідуальний рівень включеності базується на понятті суб'єктності, на отриманні особистого досвіду, на усвідомленні своїх освітніх потреб та рівня участі у груповій взаємодії кожної особливої дитини [2, с. 183].

Реалізація основних принципів інклюзивної освіти здобувачів початкової освіти 3 особливими освітніми потребами в закладах загальної середньої освіти базується на таких змістовних і організаційних підходах, методах, формах, як:

- індивідуальний навчальний план та індивідуальна освітня програма дитини 3 розвитку академічних знань і життєвих компетенцій;

- соціальна реабілітація дитини в освітній установі і поза нею;

- психолого-педагогічний супровід дитини в процесі навчання і соціалізації;

- психолого-педагогічний консиліум освітнього закладу;

- індивідуальна психолого-педагогічна карта розвитку дитини;

- портфоліо дитини з особливими освітніми потребами;

- компетентність вчителя у сфері загальної освіти з елементами спеціальної освіти, у галузіі соціальної адаптації та реабілітації;

- підвищення кваліфікації вчителів закладу загальної середньої освіти у сфері інклюзії;

- робочі програми засвоєння предметів освітньої програми в умовах інклюзивної освіти здобувачів початкової освіти відповідно до освітніх стандартів;

- тьюторський супровід здобувача початкової освіти у процесі навчання;

- адаптивне освітнє середовище - доступність класів та інших приміщень установи (усунення бар'єрів, забезпечення дружності середовища установи); оснащення освітнього процесу асистуючими засобами i технологіями (технічними засобами забезпечення комфортного i ефективного доступу), корекційно-розвиваюче предметне середовище навчання і соціалізації;

- згуртування колективу молодших школярів, розвиток навичок співпраці, взаємодії та взаємодопомоги;

- орієнтація виховної системи закладу на формування та розвиток толерантного сприйняття і відносин учасників освітнього процесу $[6$, c. 36].

Основна мета освітньої установи, яка почала шлях розвитку інклюзивної практики, - створення спеціальних умов для розвитку та соціальної адаптації здобувачів початкової освіти 3 особливими освітніми потребами та їхніх однолітків.

Найбільшою та основною умовою включення дитини 3 особливими освітніми потребами в соціальний (зокрема, освітній) простір $\epsilon$ створення універсального безбар'єрного середовища, що дозволяє забезпечити повноцінну інтеграцію дітей у суспільство. При цьому на рівні освітнього закладу ця умова доповнюється завданням створення адаптивного освітнього середовища $[3$, с. 30$]$.

Наведемо основні групи умов:

1. Матеріально-технічна база закладу освіти, особливості оснащення спеціальним освітнім і корекційним обладнанням; існуючі можливості організації дистанційного навчання як вимога часу.

2. Інформачійно-організаційне забезпечення освітнього процесу, котре включає в себе нормативно-правову базу, фінансово-економічні умови, створення інклюзивної культури в закладі освіти, взаємодію із громадськими організаціями та батьками (необхідне розроблення регламентів взаємодії із зовнішніми організаціями, локальних актів освітнього закладу, що реалізує інклюзивну практику), інформаційно-просвітницьке забезпечення.

3. Організаційно-педагогічне забезпечення, що включає реалізацію освітніх програм із урахуванням особливостей психофізичного розвитку та можливостей дітей із особливими освітніми потребами. Забезпечення можливості засвоєння освітньої програми згідно з індивідуальним навчальним планом.

4. Програмно-методичне забезпечення освітнього процесу. Реалізація варіативних форм і методів організації навчальної та позанавчальної роботи. Використання різних видів освіти. Застосування сучасних технологій освіти і психолого-педагогічного супроводу. Адаптація методик навчання i виховання до особливих освітніх потреб дітей.

5. Комплексний психолого-педагогічний супровід, організація корекційної роботи.

6. Кадрове забезпечення. Спеціальна підготовка педагогічного колективу до роботи 3 дітьми 3 особливими потребами, роботи в умовах інклюзивної практики [4, с. 14-18].

Стратегія розвитку освіти за принципами інклюзії, яка зачіпає всі зазначені рівні змін, безумовно, є довгостроковою, орієнтованою на стратегічне управління та соціокультурну динаміку.

Актуальний етап у розвитку освіти дітей 3 обмеженими можливостями здоров'я орієнтований на стандартизацію всіх системних процесів, що забезпечують доступність і якість освітніх умов і послуг. Проблема полягає в тому, що 
інклюзивна освіта в багатьох випадках реалізується як переведення дітей $з$ особливими освітніми потребами в звичайний заклад загальної середньої освіти, проте спеціальні освітні умови там не створюються [7, с. 37]. Багато дітей 3 особливими освітніми потребами часто здобувають освіту вдома дистанційно. Відсутність спеціальних умов, архітектурна недоступність i недостатність коштів стають об'єктивними причинами для стратегій виключення. Інклюзію приймають як гуманістичну ідею, проте не вірять в ії реальність [7, с. 36].

Психологічні бар'єри, як і раніше, залишаються основними перешкодами в реалізації завдань інклюзивної освіти. Таким чином, створення спеціальних умов для отримання освіти дітьми 3 особливими потребами пов'язане не тільки і не стільки зі створенням певної матеріально-технічної бази освітнього закладу, скільки зі зміною всього освітнього середовища.

Діти з особливими освітніми потребами вимагають спеціального підходу до їхнього навчання, розвитку, виховання, особливих педагогічних умов під час організації навчальної і виховної діяльності за рахунок реалізації психолого-педагогічного супроводу.

Психолого-педагогічний супровід - це комплексна система педагогічних заходів зі створення усіма суб' єктами освітнього процесу соціально-психологічних і педагогічних умов для надання допомоги і підтримки дитини з особливими освітніми потребами у вирішенні завдань iii розвитку, навчання, виховання і соціалізації в інклюзивному освітньому просторі.

Відповідно до думки І.А. Юдіної, система психолого-педагогічного супроводу в умовах масової загальноосвітньої школи виконує низку функцій. Компенсаторна функція полягає у створенні умов, що забезпечують розвиток дитини 3 особливими освітніми потребами поряд зі здоровими дітьми.

Стимулююча функція спрямована на активізацію дитини в процесі спілкування в суспільстві здорових дітей. Розвиваюча функція передбачає створення умов для нормальної соціалізації дітей з особливими освітніми потребами. Корекційна функція виступає процесом психолого-педагогічної підтримки, передбачаючи корекцію травмуючих впливів на дитину і нейтралізацію факторів, що викликають вторинні або психологічні наслідки дефекту [1 с. 185].

Під час здійснення психолого-педагогічного супроводу здобувача початкової освіти з особливими освітніми потребами в закладі загальної середньої освіти бажано дотримуватися низки умов: по-перше, прийняття чинників, що зумовлюють наявність у дитини особливих освіт- ніх потреб, та їхній вплив на специфіку оволодіння навчальною програмою і участь у житті суспільства; по-друге, орієнтація на суб'єктне включення учня і його сім'ї в загальний процес освітньої інклюзії; по-третє, створення для цього процесу особливої форми життєдіяльності учня - спеціального розвиваючого середовища, організація якої залежить від педагогів.

Психолого-педагогічний супровід слід вести за чотирма напрямами. У межах першого напряму (адаптаційний етап) необхідно провести роботу 3 дитиною і членами іiі сім'ї на етапі вступу до школи. Другий напрям має на увазі надання психолого-педагогічної підтримки дитині в умовах школи з метою розвитку її комунікацій. В основі третього напряму лежить надання індивідуальної психолого-педагогічної допомоги дитині 3 особливими освітніми потребами в процесі їі навчання в умовах масової загальноосвітньої школи. Четвертий напрям має охоплювати роботу з педагогічним колективом [1, с. 29].

В.В. Хитрюк підкреслює, що ключовою фігурою інклюзивного освітнього простору $є$ вчитель, який вирішує низку професійних завдань щодо забезпечення психологічного комфорту в освітньому процесі для всіх дітей. При цьому слід пам'ятати, що успішність такої роботи багато в чому залежить від узгодженої професійної взаємодії вчителя $з$ іншими учасниками інклюзивного освітнього простору - групи супроводу особливої дитини, такими як: вчителі-дефектологи, педагог-психолог, соціальний педагог, батьки як звичайних, так і особливих дітей $[4$, с. 17$]$.

Інклюзивний освітній простір базується на наданні варіативних форм навчання для дітей із різними стартовими можливостями. Навчальні плани і цілі підлаштовуються під здібності і потреби учнів. У цьому процесі суттєве значення має роль вчителя, який працює над тим, щоб кожна дитина могла вчитися 3 найбільшою для себе користю. При інклюзивному підході виграють всі учні, оскільки він робить освіту більш індивідуалізованою. Реалізація індивідуального підходу передбачає врахування запитів і потреб дітей з різними типами психофізичного розвитку; вибір форм, методів і засобів навчання та виховання 3 урахуванням індивідуальних освітніх потреб кожного учня, в тому числі дотримання прав на освіту дітей 3 нормативним темпом розвитку.

Висновки. Таким чином, інклюзивна освіта $\epsilon$ інноваційним явищем у розвитку національної системи освіти і закріплюється на законодавчому рівні. У зв'язку з цим особлива увага приділяється психолого-педагогічному супроводу здобувачів початкової освіти 
3 особливими освітніми потребами. У процесі становлення інклюзивного освітнього простору важливе значення відводиться вчителю, котрий допомагає проводити діагностику, адаптувати і створювати нові освітні та корекційно-розвиваючі програми для адекватного навчання здобувачів початкової освіти 3 особливими освітніми потребами.

\section{ЛІТЕРАТУРА}

1. Гоцко Г.І. Особливості організації освітнього процесі в умовах реалізації основних засад інклюзивного навчання. Інклюзивне навчання в Новій українській школі: Матеріали міжнародної науковопрактичної конференції «Інклюзивне навчання в Новій українській школі» (26-27 березня 2018 р., м. Теребовля): у 2 ч. Інститут спеціальної педагогіки НАПН України; упорядн.: Лапін А.В., Сурмай Л.О., Щуцька О.І. Київ: Інтерсервіс, 2018. С. 28-30.

2. Лапа В.М. Інклюзивне навчання як передумова розвитку комунікативної толерантності старшокласників та модель iï формування у процесі внутрішікільної інтеграції. Теоретичні $і$ прикладні проблеми психологї. 2018. № 1. С. 181-198.

3. Недомовна В. Інклюзія - вимога часу. Перші кроки до інклюзії. Директор школи. 2016. № 9/10. С. 29-35.

4. Недомовна В. Успішна інклюзивна освіта: співпраця батьківської спільноти та школи Директор школи. 2016. № 1/2. С. 12-19.

5. Ольшевський В. Проектний метод: ефективний спосіб навчання у спеціальних школах. Сучасна школа України. 2017. № 7. С. 27-31.

6. Островська К. Тенденції розвитку інклюзивної освіти в Україні: комплексний підхід. Без Бар'єрів. 2017. № 5/6 (берез.) С. 3-6.

7. Петух О.В. «Українська» інклюзія: їі місце та роль в освіті. Управління школою. 2015. № 19/20/21. C. 36-37.

\section{REFERENCES}

1. Hotsko, H.I. (2018) Osoblyvosti orhanizatsii osvitnoho protsesi v umovakh realizatsii osnovnykh zasad inkliuzyvnoho navchannia [Features of the organization of the educational process in the implementation of the basic principles of inclusive education] Inkliuzyvne navchannia v Novii ukrainskii shkoli: Materialy mizhnarodnoi naukovopraktychnoi konferentsii «Inkliuzyvne navchannia v Novii ukrainskii shkoli» (26-27 bereznia 2018 r., m. Terebovlia): u 2 ch. Instytut spetsialnoi pedahohiky NAPN Ukrainy; uporiadn.: Lapin A.V., Surmai L.O., Shchutska O.I. Kyiv: Interservis, 2018. Pp. 28-30 [in Ukrainian].

2. Lapa, V.M. (2018) Inkliuzyvne navchannia yak peredumova rozvytku komunikatyvnoi tolerantnosti starshoklasnykiv ta model yii formuvannia u protsesi vnutrishikilnoi intehratsii [Inclusive education as a prerequisite for the development of communicative tolerance of high school students and a model of its formation in the process of intra-school integration] Teoretychni i prykladni problemy psykholohii. 2018. № 1. Pp. 181-198 [in Ukrainian].

3. Nedomovna, V. Inkliuziia - vymoha chasu. Pershi kroky do inkliuzii [Inclusion is a matter of time. The first steps to inclusion] Dyrektor shkoly. 2016. № 9/10. Pp. 29-35 [in Ukrainian].

4. Nedomovna, V. Uspishna inkliuzyvna osvita: spivpratsia batkivskoi spilnoty ta shkoly [Successful inclusive education: cooperation between the parent community and the school] Dyrektor shkoly. 2016. № 1/2. Pp. 12-19 [in Ukrainian].

5. Olshevskyi V. Proektnyi metod: efektyvnyi sposib navchannia u spetsialnykh shkolakh [Project method: an effective way of teaching in special schools] Suchasna shkola Ukrainy. 2017. № 7. Pp. 27-31 [in Ukrainian].

6. Ostrovska K. Tendentsii rozvytku inkliuzyvnoi osvity v Ukraini: kompleksnyi pidkhid [Trends in inclusive education in Ukraine: an integrated approach] Bez Barieriv. 2017. № 5/6 (berez.) Pp. 3-6 [in Ukrainian].

7. Petukh O.V. «Ukrainska» inkliuziia: yii mistse ta rol v osviti ["Ukrainian" inclusion: its place and role in education] Upravlinnia shkoloiu. 2015. № 19/20/21. S. 36-37 [in Ukrainian]. 